Utah State University

DigitalCommons@USU

$10-4-2011$

\title{
Library and University Press Integration: A New Vision for University Publishing
}

Richard W. Clement

Utah State University

Follow this and additional works at: https://digitalcommons.usu.edu/lib_pubs

Part of the Library and Information Science Commons

\section{Recommended Citation}

Clement, Richard W., "Library and University Press Integration: A New Vision for University Publishing" (2011). Library Faculty \& Staff Publications. Paper 104.

https://digitalcommons.usu.edu/lib_pubs/104

This Article is brought to you for free and open access by the Libraries at DigitalCommons@USU. It has been accepted for inclusion in Library Faculty \& Staff Publications by an authorized administrator of DigitalCommons@USU. For more information, please contact digitalcommons@usu.edu.

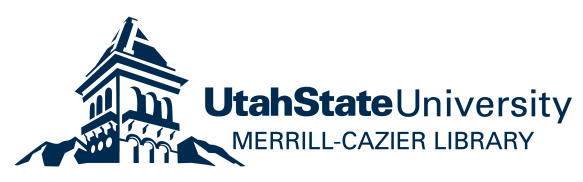


Library and University Press Integration: A New Vision for University Publishing ${ }^{1}$

\author{
Richard W. Clement \\ Utah State University
}

The crisis in university publishing seems to have inexorably come to a head. A combination of factors has effectively halted the establishment of new presses and simultaneously challenged the viability of many of the remaining ninety or so American university presses. Several presses have closed and almost all are struggling to find a way to remain true to their mission of publishing scholarly monographs and at the same time achieving and maintaining selfsufficiency. For many it is a nearly impossible conundrum. Presses have tried various editorial tactics and new publishing strategies to keep afloat, and while a few have had some success, the larger economic situation has continued to erode their ability to succeed. In the face of what appears to be insurmountable impediments, some university presses have turned to university libraries as natural partners in the enterprise of distributing scholarship and research. Though these two entities have differing business models, partnerships have much to offer each. Indeed, integrating the press into the library organization and aligning its business plan with the library's offer a viable solution to the crisis of contemporary university publishing.

This article is primarily concerned with publishing scholarly monographs, not scholarly journals. While some US university presses publish scholarly journals, most do not, and journal publishing is quite distinct from book publishing. Most library/press partnerships involving journals have consisted of digitizing back issues or helping with open access initiatives. In point of fact, most library-sponsored open access journals are published through the library's institutional repository and not as part of a press partnership. Scholarly monographs on the other hand are very much in a state of flux and library/press integrations have the potential to be extraordinarily significant in the future development of publishing in this area. This article will first review the history of university presses in the United States, then consider the nature of the challenge now facing presses to succeed, and finally offer a new model for press and library integration as exemplified in such a merger at Utah State University.

\title{
University Presses in the United States
}

University presses are nearly as old as the printing press itself, but modern university presses in the United States developed in the last part of the nineteenth century. ${ }^{2}$ As the new research universities were founded and older universities were transformed, a press was seen as a

\footnotetext{
${ }^{1}$ With thanks to Michael Spooner, Director of the Utah State University Press, Patrick Alexander, Director of the Penn State University Press, Phil Pochoda, Director of the University of Michigan Press, Sandy Thatcher, Director Emeritus of the Penn State University Press, and Charles Watkinson, Director of the Purdue University Press, for reading earlier versions of this article and offering criticism. Of course the article and any errors remain my own. An earlier version was delivered as a paper at a jointly sponsored seminar by the Association of Research Libraries and the Society for Scholarly Publishing, Partnering to Publish: Innovative Roles for Societies, Institutions, Presses, and Libraries, November 10, 2010, <http://www.arl.org/sc/models/lib-publishing/ partnering2publish/index.shtml>

${ }^{2}$ For a general treatment of university presses within the larger context of the history of American publishing, see Tebbel (1972-1978), vol. 2, pp. 535-539; vol. 3, pp. 279-285; for a more narrative and coherent account, see Givler (2002).
} 
necessary tool for disseminating the university's research and scholarship. In other words, the press was essential to fulfilling a major aspect of the university's mission. Recognizing that centrality, university presses were established with significant subsidies and were never expected to be profitable. Daniel Coit Gilman, in founding Johns Hopkins, recognized the centrality of the press to the university. ${ }^{3}$ Only two years later in 1878 in establishing the university press, he said: "It is one of the noblest duties of a university to advance knowledge and to diffuse it not merely among those who can attend the daily lectures but far and wide" (Johns Hopkins University Press, 2010).

Though Cornell seems to have established the first American university press in 1869, it closed in 1884 (following the closure of its journalism program in 1878), only to be resurrected in 1930. Beginning at the end of the nineteenth century a steady progression of newly flourishing presses was evident at Johns Hopkins (1878), Pennsylvania (1890), Chicago (1891), California (1893), Columbia (1893), Baylor (1897), Princeton (1905), Fordham (1907), Yale (1908), Washington (1909), Harvard (1913), Marquette (1916), New York (1916), Illinois (1918), Duke (1921), North Carolina (1922), Minnesota (1925), Stanford (1925), Duquesne (1927), Washington State (1927), Oklahoma (1928), New Mexico (1929), and Michigan (1930). By 1930 there were 24 university presses in the United States. The following chart (figure 1) illustrates the number of presses established by decades (AAUP, 2009). Clearly from about 1921, presses were being established with regularity and were perceived to be an essential part of both large public and private research universities. This trend accelerated through the 1930s and 1940s, saw a slight hiatus in 1953-55, and then shot up as part of the overall expansion of American higher education in the post-Sputnik era. The year 1972 marked the turning point as the number of newly established presses significantly declined.

\footnotetext{
${ }^{3}$ The use of the word "subsidy" to describe the financial support provided by a university to its press is one that bothers some press directors. The financial support provided by central administration to the library (or almost any other unit) is never termed a subsidy. It is simply financial support. And the support for a library or other unit is at a much higher level than the subsidy provided to a press. However, the persistence of "subsidy" to describe support for the press is directly related to the business model of the press. Should the press adopt the library's business model, as I advocate below, the use of "subsidy" would quickly disappear.
} 


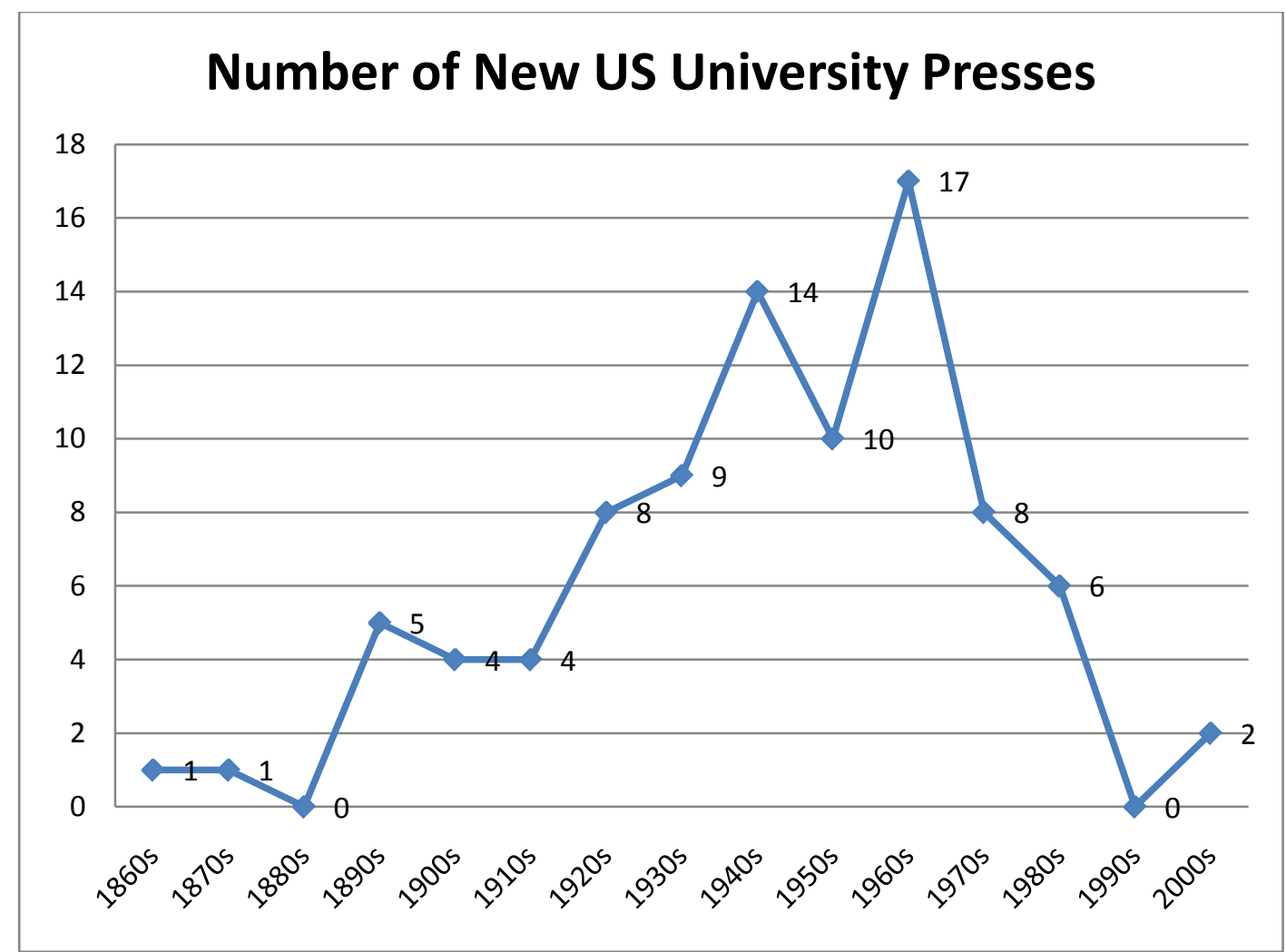

Figure 1

Another way of considering these data is shown in figure 2. Here we see the total number of university presses beginning to level off in the 1980s with no significant increase thereafter. Have university presses reached a natural plateau, or are other factors at work? As further analysis will show, quite clearly other factors have influenced the growth in establishing new presses, but the question of a natural plateau is worth asking. Perhaps most research universities in the United States already have university presses, and thus the leveling of numbers in the 1990 s and 2000s reflects that fact. However, a quick glance at national education statistics indicates that in 2007 there were 277 research universities in the United States (IPEDS, 2008). Thus, about a third of US research universities now have presses. There are still 189 research universities without presses. Do all research universities need presses? Clearly not, but the more pertinent question is whether research universities need presses anymore. 


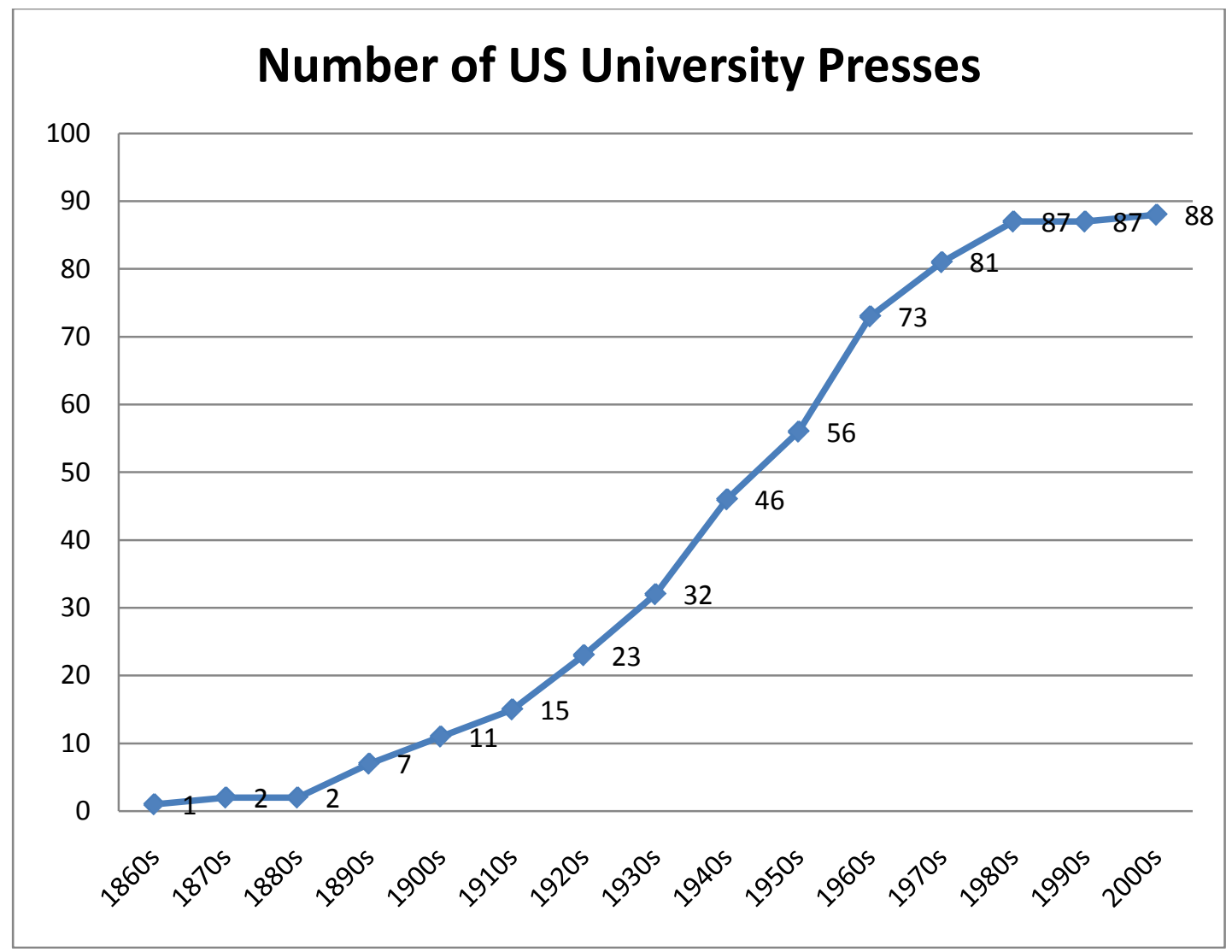

Figure 2

The core mission of a university press remains the publication of high-quality scholarly monographs, but the peer-review process used to select monographs has now assumed a central role in the certification process associated with awarding tenure and/or promotion. Given the importance of this validation process to the academy, there can be no doubt that research universities need this service. ${ }^{4}$ But does each research university need a press? Each research university needs the services offered by a press, but less than a third is willing to support its own press. And in point of fact almost all of the 2,719 colleges and universities in the US offering bachelor's degrees or higher (NCES, 2009) require the peer-reviewed certification provided by

\footnotetext{
${ }^{4}$ The origins of peer review for American university press scholarly monographs are to be found in the editorial boards or committees that oversee the presses. Monographic projects were typically reviewed by these committees and no doubt occasionally manuscripts were sent out for external review. It appears that formal external peer review developed after World War II. Nowhere does Lane (1942) even mention peer review or a similar process in his study of university presses up to the end of the 1930s. Similarly, Weller (2001, p. xii) begins her study of peer review in journals with 1945 because she could find no references to it before that date. We know that formal peer review began in certain scientific and medical journals in the 1940s, but it was not until the 1960s that double-blind peer review became nearly universal for scholarly journals (Burnham, 1991; Spier, 2002). Spier suggests that the introduction of photocopy machines in 1959 had a major impact on peer review, as copies of manuscripts could now be easily distributed to reviewers (p. 358). I have been unable to find any discussions of peer review with reference to scholarly monographs, but Burnham's conclusion concerning biomedical journals is apt: "The very untidiness of the historical record of the development of editorial peer reviewing suggests the complexities that are involved in the functioning of the institution as it has matured in the late 20th century" (p. 22).
} 
about 88 US university presses. ${ }^{5}$ The result is that there is a huge pressure to publish ever-more peer-reviewed monographs to certify faculty moving through the tenure and promotion process, regardless of market viability or press capacity.

When many university presses were first established in the early 20th century, they often produced a wide range of publications the university required. Chief among them were scholarly monographs that were usually authored by their own faculty across many different disciplines. ${ }^{6}$ The press list looked rather chaotic, like the university itself. ${ }^{7}$ But over time, press directors, faculty, and administrators all agreed that presses should concentrate on scholarly monographs and they ought not to publish just their own faculty. This avoided the perception of a conflict of interest for the press and built a national reputation for the university (Gump, 2006). Of course most presses have continued to publish some of their own faculty, but at a greatly diminished level (at some institutions as low as 5\%, but at others as high as 25\%). But as Paul N. Courant (2010) notes: "Most reputable presses make it a point of pride that faculty from the home institution are subject to the same quality standards for publication as are faculty from other institutions. And most press boards, tenure committees, department chairs, and others who are part of the system of refereed scholarly publishing defend vigorously against possible charges that their publications are in any way a "vanity press' for the local faculty." An unintended consequence of publishing faculty from other institutions has been to make the press less known to its own faculty. As fewer and fewer local faculty have published with their own university's press, fewer faculty know of and support the press. The majority of faculty who know of the press are at other institutions. This has resulted in increasing local isolation for the press.

The gradual local isolation of the press has decoupled its mission from the mission of its host university and moved it out into the more diffuse realms of academia at large. The result has been the local marginalization of the press (and in some instances the literal marginalization as presses were physically moved out to the edge of campus, or even beyond). In good budgetary times, this has not mattered much as a marginalized press still brought national distinction and prestige to its home institution, but in bad budgetary times the press often lacked local political weight to withstand attempts to reduce its subsidy. Thus presses have suffered from periodic budgetary pressure and a steady reluctance by central administration to fund fully university publishing. As a result the number of scholarly monographs published has failed to keep up with the demand and increasing pressure from the tenure and promotion system. This has been described as the "Crisis of the Scholarly Monograph." 8

\footnotetext{
${ }^{5}$ This is the "free rider" complaint that many press directors voice. It is an issue that has long been recognized, but continues to deepen; see National Enquiry (1979), particularly Recommendation 8, pp. 24-26; and pp. 123-124.

${ }^{6}$ See Tebbel (1972-1978, vol. 2, pp. 535-539) on the early history of several university presses. Lane (1942, p. 17) notes "There can be little doubt that many university presses, especially those with manufacturing plants, were often established in order to do institutional printing. Allied with this was the argument that students in Journalism required a printing laboratory. The theory that a university press was a means for publishing the product of research, that it would enhance the reputations of scholars and institutions, developed relatively late in American university press history." Of course from our perspective "late" is relatively early. Certainly by 1920, and in many instances well before, the concept of the university press as primarily a publisher of high-quality scholarly books was well established.

${ }^{7}$ Lane (1942, pp. 143-144) notes that some presses specialized in these early years, but that many simply "published whatever was offered and subsidized."

${ }^{8}$ The Modern Language Association in 1999 established an ad hoc Committee on the Future of Scholarly Publishing which issued a report in 2002 (MLA, 2002). The central problem identified by the committee is the inability of
} 
Perhaps this is the place to interject a cautionary note. The world of the 90 or so US university presses is not monolithic. While there are certainly larger trends that have affected all organizations, the responses have been varied, particularly in relation to a press' ability to be innovative and at the same time to absorb losses. Some of the largest presses, such as the University of Chicago Press, have such depth, reputation, and breadth in their publishing programs (including such profitable services such as their distribution center) that many of the effects of the crisis have been minor and such presses have had the resources to respond proactively (though even the nation's largest university press has not been immune to crises). At the other end of the continuum are the small presses, such as my own at Utah State University. These are the presses most at risk, and yet many still manage to hang on and remain in the black (though of course only because of subsidies). Still, as the next disruption bursts upon us, requiring forward thinking and an investment of resources, the smaller presses may be unable to cope. And in the middle are most of the nation's university presses, some with strengths such as significant regional lists, independent endowments, and strong administrative support, but most nonetheless must cope with the critical challenges discussed below.

\section{The Crisis in Publishing Scholarly Monographs}

University presses soared along with their parent institutions through the good years for higher education of the late $50 \mathrm{~s}$ and the $60 \mathrm{~s}$. Likewise, they have suffered with their parent institutions in the lean years that followed, but presses have been uniquely challenged with a series of very serious problems that have exacerbated the situation to the point where some presses could no longer continue. The literature is rich with articles and opinions regarding "the problem." In 2004 Cathy Davidson, Vice Provost for Interdisciplinary Studies at Duke University, summed up the complexity of "the problem":

The problem is that we have tied tenure to the publication of a scholarly book. No, others say: uncoupling tenure from books cannot solve the problem because journals are in trouble, too. Others suggest that the problem is the scholarly monograph itself, or that the problem is curtailed library spending on humanities books. The problem is price-gouging by commercial publishers of science journals, forcing libraries to spend less money on humanities and social science publications. The problem is chain bookstores, the dwindling number of independent bookstores, and the increasing conservatism of those that remain. The problem is electronic booksellers like Amazon.com, with their heavy discounting and selling of used books. The problem is that books cost too much to produce. The problem is that electronic publishing is too expensive and doesn't work for monographs. The problem is shrinking subsidies to presses in the wake

\footnotetext{
university presses to keep up with the need of faculty moving through the promotion and tenure process for the publication of scholarly monographs. The report sums up very well the issues involved and then asks the question: "how can ever-increasing demands for publication as a qualification for tenure and promotion be sustained when scholars find it harder and harder to publish their books?" (p. 176). The committee makes a number of recommendations, but confesses that they have "come to understand that there is no ready or simple solution to the current crisis" (p. 182). While acknowledging the future potential for eBooks, no clear path forward for digital scholarly monographs was visible at the time the committee was deliberating. That has now changed with the passage of a decade and perhaps the time has come for a new committee to revisit the topic.
} 
of cutbacks to higher education for state universities. The problem is shrinking subsidies to presses in light of dwindling returns on endowments and diminished philanthropy at private universities. The problem is that many universities that depend upon academic publications (books or journal articles) to award tenure don't have presses of their own - they are "mooching off" everyone else. The problem is the corporatizing of the university. The problem is the sciences. The problem is the changing demographics of higher education: there are fewer assistant professors and graduate students, who are the primary book buyers (as well as the primary authors of articles in refereed journals). The problem is that the course pack has been substituted for the assigned secondary classroom text. The problem is that the jargon of postmodern critical theory has shrunk the audience for the humanities. The problem is that the critical theory boom has ended, and no one is excitedly reading every new book any more. The problem is that, since $9 / 11$, people are watching CNN and not buying books, trade or academic. The problem is that university press books are underpriced relative to their production costs. The problem is that university press books cost too much relative to the income of their target audience. The problem is too many books. The problem is too few books. The problem is too many books of one kind and too few of another. The problem is that students don't know how to read any more. The problem is that almost all of the above are part of the problem (Davidson, 2004, pp. 130-131).

For university presses the most immediate problem was that unit sales of scholarly monographs had declined by $75 \%$ since the 1970s (Thompson, 2005, p. 94). Whatever the reasons for this precipitous decline, presses had to develop strategies to stay afloat. Few could count on new subsidies from their host institutions. And most host institutions were expecting presses to be self-sufficient (including subsidies). Among the most common strategies were to reduce costs, increase prices, change publishing strategies, alter the list, expand marketing, or publish other kinds of books. ${ }^{9}$

Reducing Costs and Increasing Prices. Presses have had more success with reducing costs than with increasing prices. The whole process of editing and producing a book has been transformed as new digital technologies have been adopted, and most of these have provided some costsavings. ${ }^{10}$ This has been most evident in reducing typesetting costs as page design software has replaced the traditional typesetter who used to key in text, but every aspect of the process has been transformed. Scholarly presses have always valued high-quality production (both editorial and design) as emblematic of their intellectual content and many have been loath to change. Though more often seen in commercial scholarly presses, some university presses also adopted measures that forced authors to use standardized templates, cover designs were standardized and simplified, lower quality materials were used, and cheaper bindings were adopted. It was hoped that even if the physical book was of lesser quality, the intellectual content remained high. Some presses even went further by requiring the author to produce camera-ready-copy (now in the form of a PDF), thus saving all typesetting and copyediting costs. But in the face of significant

\footnotetext{
${ }^{9}$ These strategies are discussed in detail in Thompson (2005), pp. 112-166.

${ }^{10}$ For a summary of an editor's duties see Thatcher (1999) and for the transformation behind the scenes see Thatcher (2009a).
} 
criticism, this radical approach has not been widely adopted. Most university presses have resisted strategies that resulted in a reduction in intellectual quality (unlike some commercial scholarly presses), but almost all were transformed by digital technology and many adopted reductions in physical quality - all in an attempt to save money.

One of the most common and successful strategies has been to outsource functions such as copyediting. (Presses learned long ago the benefits of outsourcing printing and binding.) Rather than employing a number of in-house manuscript editors, presses have moved to contract with freelance editors to provide editing services. Likewise, graphic design has also often been outsourced. Some smaller presses have contracted with larger presses for fulfillment services, warehousing, and now digital services. These strategies have been effective in reducing costs. For some, particularly smaller presses, the staff now consists of a director, a few acquisitions editors (who also handle marketing), and a secretary.

The other side of reducing costs is to raise prices. While it has been relatively easy for most US university presses to increase backlist prices to better reflect the current market, adjusting new title prices upward has been more difficult. Certainly new title prices for monographs have increased over the years, but from 1986 to 2000 the increase of $66 \%$ was little more than the $57 \%$ increase in CPI. So in real terms, this was only a small increase and most of this came in the 1980s. If we look at the 1990s, we see an average unit price of $\$ 16.55$ in 1991 and an average unit price of $\$ 16.77$ in 2000. In contrast, British university presses and commercial scholarly publishers have raised prices to about double that of US university presses; in 2002 the average hardback scholarly monograph published by a British scholarly press cost $\$ 80-95$, while a similar book published by an American university press cost $\$ 40-50$ (Thompson, 2005, pp. 116117). Some US university press directors have been unwilling to follow the British lead. They argue that higher prices will diminish the market for individual scholars to purchase books. Many consider it a part of the unique mission of a university press to keep prices relatively low, particularly to keep press books attractive for course adoptions. In some disciplines, particularly STEM, prices have moved up significantly, but in others, prices have only moved up moderately. Still, compared to British academic press book average prices, average US press book prices remain relatively low.

Changing Publishing Strategies. Traditionally a scholarly monograph was issued in cloth, mostly for the library market. A paperback edition might be issued if demand warranted. Beginning in the 1970s publishers began to issue hardback and paperback editions simultaneously, with some success. In $198617.5 \%$ of titles were published simultaneously and by 2000 this had increased to $31.8 \%$ (Thompson, 2005, p. 119). But at the same time libraries were buying fewer and fewer monographs and beginning to prefer paperback to hardback (as a moneysaving factor). Sales data show a clear trend that paperbacks overtook hardbacks in the mid-90s and are continuing to increase that sales gap (Thompson, 2005, p. 121). But paperbacks are not nearly as profitable as hardbacks and generally have a lower margin. Thus a publisher must sell a larger number of paperbacks to equal the profits derived from a cloth edition. Many hoped for paperback course adoptions that would lift the press into the black, and while this happened to some degree, too often paperback editions sold too few copies and depressed the sales of the hardback editions. In some instances sales for cloth editions had fallen to as few as 200 copies. If paperback sales were equally lackluster, the press was on a path to disaster. As a result most presses have abandoned 
simultaneous publishing and gone back to issuing a cloth edition, followed by a paperback edition if warranted. But we now have a further complication with eBooks. Should there be simultaneous eBook publication with the print (cloth and/or paper) publication? Librarians certainly think so, but publishers are hesitant because they see the potential for a single eBook in a library collection to shut down multiple sales for any other format, including other copies of the eBook. ${ }^{11}$ The problem lies in the business model, and it does not appear to be working for many presses. With the advent of the eBook, the current business model looks even more problematic.

Altering the List. As many presses were instructed by university central administrations to become self-sufficient (in many cases maintaining an established subsidy, but now requiring sales revenue to cover manufacturing costs), press directors began to emulate trade publishers by altering and consolidating their lists. Many lists were traditionally fairly broad with little depth. Presses published worthwhile books in many diverse subjects, but most had some subject concentrations and here is where directors tended to direct their attention. From a trade perspective it made sense to build the list in one or several areas and then stop publishing in all other areas. This enabled specialist editors proactively to commission titles in their subject areas. It also tended to build reputation for the press and its parent institution in those areas of concentration, but, as already pointed out, it also isolated the press from faculty in all but a select few disciplines. Some presses, such as MIT, concentrated in several of those areas central to the institution and succeeded all round, but many other presses concentrated in disciplines or areas of little interest to their institutions. And as long as the central administration paid little attention to the press (but kept supporting it), list consolidation was a good move in maintaining selfsufficiency. But as various budget crises have hit over the past few decades, administrators have begun to question the centrality of a press that publishes in areas that are not central to the university itself. As a result many presses have continued to be challenged to be self-sufficient and a few have even closed their doors.

Expanding Marketing. The overriding criterion for accepting a university press book has traditionally been scholarly quality as evidenced in the peer-review process, and marketing and sales staff were only involved after a book had been produced. However, as presses consolidated and specialized their lists, this allowed for much more sophisticated and targeted marketing. This encouraged marketing and sales staff to become part of the decision-making process to acquire and publish a book. If a book did not seem likely to sell in sufficient numbers, then it should not be published in the first place. While this is standard in trade publishing, it has been a new development in academic publishing. Of course this emphasis on marketability has led inexorably away from scholarly monographs, which are the least marketable books, and into other arenas for more marketable books.

Publishing Other Kinds of Books. University presses have always published a broad variety of books, not just scholarly monographs. But, as we have seen, declining subsidies and the move to self-sufficiency have forced presses to move in a significant way into other more profitable

\footnotetext{
${ }^{11}$ How eBooks affect sales is directly related to digital rights management (DRM). The publishing industry strongly advocates rigorous DRM, while libraries equally strongly advocate no DRM. Collaborative efforts between university presses and libraries, such as Project Muse, or collaborative press efforts, such as the University Press eBook Consortium, have very little DRM because of librarian involvement.
} 
publishing areas. The foremost of these areas is trade publishing, but textbook publishing and regional publishing are also significant. Some presses have also entered into professional and reference publishing.

There is a natural overlap in the world of scholarly publishing between university presses and trade houses such as Penguin, Norton, Basic Books, or The Free Press. (In many ways Oxford University Press and Cambridge University Press are more like these kinds of trade houses than the typical US university press.) These trade houses specialize in publishing scholarly books for the general public and at prices much lower than scholarly monographs, but in much larger press runs. The overlap between these two kinds of publishers has been called academic-trade publishing, and the lure for a university press is readily understandable. A successful university press book in this market can sell thousands of copies in cloth generating significant frontlist income, and then a paperback edition can continue to build very significant revenue, particularly if it is adopted for university courses. Compared to the level of revenue generated by scholarly monographs, there can be little comparison. But there are risks attached to academic-trade publishing for university presses, and a significantly greater investment must be made up front, particularly in terms of author advances and much larger print-runs. A successful trade book requires a very significant publicity and media campaign to get the books into the bookstores and then customers to purchase copies. Further, the discount on a trade book is deeper than on a scholarly monograph, typically $40-50 \%$ as compared to $20-30 \%$. And then there can be massive returns for all the books left unsold in bookstores. Nonetheless, some university presses, such as Harvard, have been quite successful in the trade market. While any successful university press could certainly argue that publishing academic-trade books fulfills its mission to disseminate scholarship, in point of fact few such titles are considered as legitimate in the university credentialing process for tenure and promotion. Only scholarly monographs have that legitimacy. But I suspect there is hardly a single press director who would not jump at the chance of publishing a successful academic-trade book. The problem comes when, after such a significant investment, the trade book flops. Few university presses have the reserves to absorb very many failures.

Regional publishing is a natural area that many university presses have long taken advantage of. Indeed many press directors would argue that publishing that focuses on the host institution and the surrounding region is undoubtedly within the mission of the press. And clearly serious scholarly works that have a regional focus would be appropriate. But what about a lavish largeformat photographic treatment of historic homes in the university's hometown? Would such a book, if written by a faculty member, enter into the university credentialing process? Probably not, but there are regional books that, though they do not support the press' mission to publish original scholarship, are nonetheless important for the university itself, particularly as an element of outreach. Regional publishing often has a legitimate place in a university press' publishing program, but care must be taken not to damage or dilute the press' reputation for high-quality scholarship.

To move into textbooks would seem a natural extension for university presses, but in point of fact the textbook publishing business is very different from academic or trade publishing. Some large presses such as Oxford and Cambridge have had the resources to set up separate textbook departments, but smaller presses cannot be expected to publish textbooks simultaneously with 
scholarly monographs utilizing the same editorial personnel. Monographs tend to sell most copies soon after publication with comparatively few backlist sales. Textbooks, on the other hand, are designed to have deep and consistent sales over the several years the edition is on the market (and then carry right on to the next edition). A successful textbook can generate significant revenue, but textbooks require very heavy investments up front in commissioning, advances to authors, editing (consider the huge investment in permissions for illustrations in an Art History textbook), and marketing. The US textbook market is dominated by and essentially locked up (certainly in terms of the large entry-level classes) by several large commercial publishers. But there are still openings for university presses to publish supplementary textbooks, or monographs more likely to be adopted for higher-level courses. Still, many university press editors question if textbooks fall within the mission of the press to publish original scholarship. And few faculty moving towards tenure and promotion are willing to author textbooks as they do not rank highly in that process: "the book-length monograph has become the holy grail for achieving tenure" (MLA, 2002, p. 177). But on the other hand, some faculty, particularly those who have achieved tenure and promotion, are delighted to write textbooks for substantial advances and royalties.

\section{An Old Business Model}

At this point there can be very few press directors who still think the old business model of modest university support and self-sustainability is viable, though my own experience in talking to editors and directors at the annual AAUP meeting in June 2010 suggests that many are still firmly attached to the old model even while intellectually recognizing its bankruptcy. Phil Pochoda (2010), Director of the University of Michigan Press, put it very well in describing the collective reaction to the digital revolution:

As individuals at beleaguered institutions are wont to do, the initial reaction of some at university presses consisted of circling the wagons, repeatedly intoning stale mantras of self-praise, clinging to fraying publishing practices like a security blanket, and convincing themselves (or letting their benighted professional organization convince them and others) that they could ride out this technological tsunami intact, in part by clutching ferociously to the Disney-corrupted version of the print copyright regime.

The future is uncertain, but there remains a certain comfort in the old ways. John B. Thompson's exceptional study of academic publishing charts the changes over the past forty years and the increasing inability of the old business model to deliver. ${ }^{12}$ He summarized the state of university presses as he ended his study in about 2004. "This is the fundamental paradox of academic publishing today: It is possible to survive as an academic publisher only in so far as you are able and willing to move beyond the field of academic publishing per se and to publish different kinds of books for different kinds of markets" (Thompson, 2005, p. 139). Cathy Davidson, commenting at about the same time, put it a bit more succinctly, "The bottom line is that scholarly publishing isn't financially feasible as a business model - never was, never was intended to be, and should not be. If scholarship paid, we wouldn't need university presses" (Davidson, 2004, p. 131). And certainly the events of the intervening few years have confirmed the inability of the old business

\footnotetext{
${ }^{12}$ For an excellent review, see Thatcher (2006).
} 
model to sustain the publishing of scholarly monographs. Confronted with budget cuts unimagined in previous years, the Great Recession has placed a number of presses in jeopardy. Beginning in 2008, we have seen mounting pressure from central administration to cut marginal programs and protect the core. Where do presses stand - at the core or on the margin? Too often they are on the margin.

\section{Library and Press Partnerships}

University libraries, unlike most presses, stand at the core of essential programs and at the center of the university's mission. While library budgets have been cut, and librarians periodically contemplate potential marginalization, there is very little risk of libraries being eliminated. ${ }^{13}$ From a press perspective, libraries look to be good partners that can protect them politically and financially and help move them to the center. From the library's perspective, a press offers an obvious expertise in editing and publishing, and, in particular, the production of a peer-reviewed product with an established reputation, an imprimatur. But most significantly, a press brings new pathways for interaction with faculty and engagement with the creation of scholarly content.

Partnerships between presses and libraries have a long history (Brown, 2007; Crow, 2009), but most of these have been and still are programmatic. Raym Crow (2009, pp. 6-10) summarized the range of these past and current collaborative projects:

1) Press distribution of library publications and content. This is the most traditional of relationships in which the press acts as a publisher for library publications.

2) Backlist projects in which the library undertakes digitization and hosting of some of the press' backlist titles.

3) Frontlist projects that focus on specialized works, including supplemental materials from library collections. An example is the University of Nebraska's Journals of the Lewis and Clark Expedition Online. Another kind of frontlist project publishes traditional scholarly monographs online, such as the Penn State Romance Studies series. A number of libraries host open access journals for the press on the library's institutional repository server.

4) Digital research and reference projects that draw on library collections. Examples include the University of Michigan's Middle English Compendium, the University of Virginia's Nineteenth-Century Literature and Culture, and the University of Georgia's New Georgia Encyclopedia.

5) Online publishing programs, primarily for journals. The best known is Johns Hopkins' Project Muse.

As Crow clearly shows, these projects are in almost every case partnerships between distinct entities, each bringing strengths and resources to the project, but each remaining an independent organizational unit. For these kinds of projects it matters little if the press reports to the dean of the library, as each partner maintains its own unique identity and organizational distinctness.

\section{Press Reporting Lines}

\footnotetext{
${ }^{13}$ See Greenstein (2010b) for an analysis of library funding from the perspective of a senior administrator.
} 
The traditional reporting line for the director of a university press has been to the chief academic officer of the university, although there have been many variations. One variation has been to report to the director or dean of the university library. It has been argued that this is a natural arrangement as both the press and the library distribute scholarly works, but I suspect initially that such arrangements were created in an attempt to reduce the number of direct reports to the provost and to give the press director more attention than a provost had time for. That the library represented the whole university was an added reason for moving the reporting line to the library. One of the earliest arrangements of this sort that I know of is the NYU Press, which changed reporting lines in the 1980s. And like almost all such arrangements, the press has remained operationally independent and external to the library's organization. So while this kind of parallel structure - with the press on one side and the library on the other, only coming together in the person of the library director-has become more and more popular, a true integrated approach has been very rare. (And we should note that at least one institution, Wayne State University, has gone the opposite direction, moving the reporting line from the dean of libraries to the provost in 2002.) When the Ithaka report on university publishing was issued in 2007, only 6 presses were identified as reporting to libraries (Brown, 2007, p. 48). Now at the end of 2010 at least 16 presses have reporting lines to libraries. These include the University of Arizona, University of Delaware, University of Georgia, Marquette University, University of Michigan, Massachusetts Institute of Technology, New York University, Northwestern University, Oregon State University, Penn State University, Purdue University, Stanford University, Syracuse University, Texas Christian University, University of Utah, and Utah State University.

\section{Library and Press Integration}

What are the benefits of integrating the press into the library? While at first it may seem that almost all the benefits accrue to the press, there are advantages for the library as well. But the most immediate benefits certainly are on the press side. Libraries are typically much larger organizations than presses and can provide significant logistical or indirect resources. These may include space, supplies, equipment, IT support, graphic design, public relations, legal and copyright services, and accounting services. Libraries are full of talented people who can offer part-time assistance as editors, proofreaders, or typesetters. Of course this is predicated on identifying staff who already possess the requisite skills (and as a former proofreader for a university press I do not underestimate the requirements) or who can be trained. Presses have typically outsourced these kinds of services, but by insourcing them within the library a significant cost to the press can be transformed into a modest reallocation of a few hours per week for several library staff. But the major benefit to the press is that embedded in the library it is no longer organizationally marginalized. What would give any press director pause in considering such an arrangement would be the loss of control, but ultimately a successful integration is predicated on a library dean and a press director who share a common vision.

Fewer than half of the presses that report to libraries can be said actually to be integrated into the library's organizational structure. And of course there are degrees of integration. Is the press the equivalent of a library department? Does the press report to someone other than the dean? Do press staff participate in library committees, both professional and social? Is the press located physically in the library? And the big question concerns the press budget. Is it separate, or part of 
the library budget? I have identified at least five universities that have some degree of press and library integration (University of Michigan, Oregon State University, Penn State University, Purdue University, and Utah State University); but, having only partial information about all of these institutions except my own, I will concentrate on the integration of the press and the library at Utah State University.

The USU Press is a small operation that until recently was comprised of 4.7 FTEs and was publishing about 20 monographs a year. The press had managed to stay barely in the black with a subsidy to cover three of the position lines but no other costs of publishing. Still, although it had grown from what could be called a "micro-press" in the 1990s to one that was merely "small," the press remained something of an orphan unit in the institution, assigned to the provost for historical rather than strategic reasons. Consequently, in mid-2008 it seemed that the time was right to re-conceive the press' place in the university's organization. Among the hopes for this initiative was to establish a place with long-term stability and with potential for greater integration with other campus units.

About a month before the Great Recession began in September 2008, USU Press director Michael Spooner and I proposed to the provost (who had already been thinking along these lines) that the press reporting line should change from the provost to the dean of libraries with the current subsidy simply transferring to the library. But as the budget crisis developed (and it has been far too complex to recount here) the press lost 1.7 FTEs, but more significantly it was at risk of being shut down. As the cuts mounted, the university began a process of evaluating programs and units, and strategically making cuts. Whereas some units, like the library, were judged to be central to the mission and were protected to a significant degree, the USU Press was determined to be "non-essential" in the estimation of the university budget-reduction committee. The press certainly had strong faculty advocates, but the administration was looking at very hard decisions. At one point when it looked like the university might have a total of $\$ 27,500,000$ in cuts, I have no doubt the USU Press would have been one of many difficult cuts. But in the end, we "only" suffered cuts of $\$ 21,000,000 .{ }^{14}$ The press was now down to 3 FTEs and no likelihood of returning to higher staffing levels.

The administration realized the press could not carry on at previous levels of production, and so we revived discussions of bringing the press into the library and in the fall of 2009 reached an agreement. The center of this agreement was that the press would move to digital open-access publishing utilizing the library's Digital Commons institutional repository, but without abandoning prudent business practices. ${ }^{15}$ It was our intention to change the press' business model to align it with the library's service model, though we realized this would be a process that would take time.

In early 2010 budgetary responsibility for press accounts and HR oversight were transferred to the library in anticipation of a formal transfer on July 1 . The press was constituted as a library department reporting to the associate dean for public services. The director began participating in library department-head meetings and other committees. In April the press physically moved from a separate building to newly renovated space in the library (the costs being shared equally

\footnotetext{
${ }^{14}$ The library suffered significant personnel losses, but collection and operating budgets were maintained.

${ }^{15}$ For context on the issues of open access for university press monographs see Thatcher (2009b).
} 
by the provost's office, the library, and the press). After this all press staff began to participate in library committees and social activities. With this move, library IT provided new computers for the press and took over network support from campus IT. All the shelf copies on hand, amounting to about 100 boxes, were moved into the library's automated retrieval and storage system, known as the BARN, providing automated access only a few feet away from the press' new location. (Press inventory is warehoused in a facility operated by the University of Chicago Press; indeed, database services, fulfillment and billing, POD, and eBook conversion services are also handled in Chicago.) By the time the official transfer date of July 1 came, the press had been well settled in the library. The library has also provided the press with a part-time clerical position. The insourcing described above has not yet been rolled out, but it is coming. Thus the physical and organizational integration is mostly complete.

The USU Press, like most presses, has concentrated its list in several areas of strength. These include the fields of composition studies, creative writing, folklore, Native American studies, nature and environment, and Western and Utah history. Some of these fields mirror the strengths of the university, such as folklore and regional history. But others, such as composition studies, do not. And of course there are fields in which the university has national recognition that fall outside the subject niches served by the press. This is not unusual, but explains why humanities faculty are very supportive of the press, while many faculty elsewhere have no idea the press exists. The core of books published is scholarly monographs, but a significant number are crossover academic trade books, regional trade books, and a few are textbooks. These other kinds of books produce significant revenue, particularly those books adopted for courses in the area of composition studies. Thus as we move forward to an open access model for scholarly monographs, we are also maintaining these revenue streams. As presently structured, these current revenue streams, together with the reduced subsidy transferred from the provost's office, and the contributions of the library, have enabled the press to stay in the black.

The press recently launched USU Digital Monographs, which we anticipate will become the fundamental initiative in transforming the press and truly aligning it with the library. USU Digital Monographs publishes only USU faculty, but in all fields and disciplines. Rigorous peer review is maintained. Publication is open access using Digital Commons, the library's institutional repository. Options for print-on-demand and various eReader formats are or will soon be available at a reasonable cost. We continue to make these eBooks available through nonexclusive agreements to eBook vendors and aggregators. And these modest revenue streams enable us to pay royalties. At present ten books are available in the series, two more are in press, and three proposals are under consideration. In early 2011, we will use the library liaisons to carry the Call for Proposals to all the university's departments. Of course we expect to encounter the "conflict of interest" concern of some faculty to publishing with their own press, but by emphasizing rigorous peer review and the advantages of open-access publication we hope to overcome those concerns. Naturally some faculty will prefer to publish with other presses. Nonetheless we believe that by offering timely publication, rigorous peer review, local editorial consultation, and the advantages of open access, we will probably have more submissions than we have the capacity to publish—but that is another problem.

Though we look to open access to publish scholarly monographs, we still intend to publish a range of other books in the traditional modes. One might call this a hybrid or multi-modal 
approach that will undoubtedly change over time. But presently, we look to the library and university to provide support for the open-access scholarly monographs. We look to the press to cover operating and editorial costs through revenues from POD and non-exclusive sales agreements on the scholarly monographs, and through the much greater revenues from academic trade, regional trade, and textbook sales. The mix will change, and the time may come when all press publications are open access, but at this point, though we are committed to move forward with open access, we are also determined to sustain our current financial base.

\section{A New Vision for University Publishing}

The range of university publishing and distribution is much larger than a university press or a library. There are many varied pieces from the press to journals situated in departments to extension publications and research institute reports to informational brochures and conference proceedings. The university is a publishing dynamo that ironically hardly knows in any central way what is going on from unit to unit. David Shulenburger recognized this several years ago when he called for universities to develop scholarly distribution strategies (2007). This holistic and comprehensive vision is one that has been advanced by a number of people over the past few years, but most recently by Clifford Lynch (2010). In an issue of the Journal of Electronic Publishing, contributors were asked to envision the future for university presses. Lynch asserted that "university presses [are] only one part of a portfolio of strategies to support the communication and documentation of scholarship." In the future, he sees every research university having a small press as part of the larger structure to support scholarly distribution. ${ }^{16}$ Lynch notes that he sees presses "in much closer alignment with the academic programs of their host institutions" and about half of a press' publications authored by local faculty. He sees digital books with a print-on-demand option, but presses with no physical inventory. Presses will be more collaborative in marketing eBooks in consortial arrangements (perhaps similar to the University Press eBook Consortium soon to be launched under the auspices of the AAUP). Open access may well be a major aspect of university press publishing, but there will be a mix of revenue streams. Lynch looks forward to a time when presses are part of a central network that functions as a database of scholarly monographs and provides access to them through university libraries. He sees in this kind of arrangement "a much improved alignment between the press and the parent institution." Finally, he notes that "ideally, one would like the majority of the funding to be in the form of institutional subvention ... recognizing that this underwriting is an essential part of an institution's commitment to disseminating scholarship." Paul N. Courant (2010) emphasizes: "A million dollars a year to sustain a press may seem like a lot of money to a big research university. A million dollars a year to support the publication of faculty work in the humanities is a drop in the bucket relative to the total expenditure on humanities faculty in that same university."

Taking a university press down the path of open access in times of financial constraint may seem counter-intuitive, and admittedly we would rather the times were more economically expansive. But when faced with an old business model that does not work, a product that is essential to the tenure and promotion process of the university, the shift of libraries to digital media, and the need to reengage our own faculty, the time has come to adopt the open-access model. The

\footnotetext{
${ }^{16}$ But Paul N. Courant (2010) in the same issue predicts many "small and unprofitable presses" will close, but other "publishing venues" will flourish.
} 
challenge is how to convince central administration to recognize the centrality of publishing scholarly monographs in this mode and the need for sustained support. The key is not to fixate on the past, but to look to the future and develop new strategies. Daniel Greenstein (2010a), Vice Provost for Academic Planning and Programs at the University of California's Office of the President, notes the need for "developing and implementing a coordinated publishing strategy for the university." He sees the reconfigured press within such a new strategy "as an asset that advances and helps to frame a university's strategic agenda." Clearly the time has come to create a new vision for university publishing that encompasses much more than scholarly monographs and university presses.

It is not easy to predict the future for scholarly communication, distribution, and publication across the nation, but those of us who are directly involved can help to shape the future by acting in those areas where we have influence. And that indeed is what we have been doing in the library at Utah State University as we have built the underlying foundation in our Digital Commons institutional repository to serve as a publishing and distribution platform for locally produced reports, pamphlets, theses, dissertations, journals, and scholarly monographs. The press is now part of a much larger collaborative effort, led by the library, to capture, develop, and distribute the information, the scholarship, and the research produced at Utah State University. As a publicly supported land-grant university, we are committed to open access and making the scholarly products of the university freely available to the citizens of Utah, the nation, and the world. We want to show the exceptional value returned for each dollar invested in research and how that value is returned to the public. And one of the many paths for returning that value to the public is through the open-access publications of the university press readily accessible to the public via the library's Digital Commons. 
AAUP (2009). Association of American University Presses Directory, 2010. New York: AAUP.

Brown, Laura, Griffiths, Rebecca, \& Rascoff, Matthew (2007). University Publishing in a Digital Age. New York: Ithaka.

Burnham, John C. (1991). The Evolution of Editorial Peer Review. In Peer Review in Scientific Publishing: Papers from the First International Congress on Peer Review in Biomedical Publication (Sponsored by the American Medical Association) (pp. 9-26). Chicago: Council of Biology Editors.

Courant, Paul N. (2010). What Might Be in Store for Universities' Presses. Journal of Electronic Publishing, 13(2). DOI: 10.3998/3336451.0013.206

Crow, Raym (2009). Campus-Based Publishing Partnerships: A Guide to Critical Issues. Washington, DC: SPARC.

Davidson, Cathy (2004). The Futures of Scholarly Publishing. Journal of Scholarly Publishing, 35(3), 129-142.

Givler, Peter (2002). University Press Publishing in the United States, in Richard E. Abel and Lyman W. Newman, eds. Scholarly Publishing: Books, Journals, Publishers and Libraries. New York: Wiley, 107-20.

Greco, Albert N., ed. (2009). The State of Scholarly Publishing: Challenges and Opportunities. New Brunswick: Transaction Publishers.

Greenstein, Daniel (2010a). Next-Generation University Publishing: A Perspective from California. Journal of Electronic Publishing, 13(2). DOI: 10.3998/3336451.0013.205

Greenstein, Daniel (2010b). Strategies for Sustaining the University Library. Portal: Libraries and the Academy, 10(2). DOI: 10.1353/pla.0.0093

Gump, Steven E. (2006). Prestige and the University Press. Journal of Scholarly Publishing, $37(2), 69-85$.

IPEDS (2008). U.S. Department of Education, National Center for Education Statistics, 2007 Integrated Postsecondary Education Data System (IPEDS). Number of degree-granting institutions and enrollment in these institutions, by size, type, and control of institution: Fall 2007, Table 234. < http://nces.ed.gov/programs/digest/d09/tables/dt09_234.asp >

Johns Hopkins University Press (2010). History. $<$ http://www.press.jhu.edu/about/index.html $>$.

Lane, Robert Frederick (1942). The Place of American University Presses in Publishing: A part of a dissertation submitted to ... the Graduate Library School... 1939. Chicago: University of Chicago Libraries. 
Lynch, Clifford (2010). Imagining a University Press System to Support Scholarship in the Digital Age. Journal of Electronic Publishing, 13(2). DOI: 10.3998/3336451.0013.207

MLA ad hoc Committee on the Future of Scholarly Publishing (2002). The Future of Scholarly Publishing. Profession, 172-186.

National Enquiry (1979). Scholarly Communication: The Report of the National Enquiry. Baltimore: Johns Hopkins University Press.

NCES (2009). U.S. Department of Education, National Center for Education Statistics, Digest of Education Statistics: 2009, Chapter 3: Postsecondary Education.

$<$ http://nces.ed.gov/programs/digest/d09/ch_3.asp >

Pochoda, Phil (2010). Editor's Note for Reimagining the University Press. Journal of Electronic Publishing, 13(2). DOI: 10.3998/3336451.0013.201

Shulenburger, David (2007). University Research Publishing or Distribution Strategies? ARL: $A$ Bimonthly Report, 252/253 (June/August), 6-9.

Spier, Ray (2002). The History of the Peer-Review Process. Trends in Biotechnology, 20(8), 357-358.

Tebbel, John (1972-1978). A History of Book Publishing in the United States. New York: Bowker.

Thatcher, Sanford G. (1999). The "Value Added" in Editorial Acquisitions. Journal of Scholarly Publishing, 30(2), 59-74.

Thatcher, Sanford G. (2006). Review of Thompson (2005). Journal of Scholarly Publishing, 37(2), 148-153.

Thatcher, Sanford G. (2009a). The Hidden Digital Revolution in Scholarly Publishing: POD, SRDP, the "Long Tail," and Open Access. Against the Grain, 20(7), 60-63.

Thatcher, Sanford G. (2009b). Open Access and the Future of Scholarly Communication, Against the Grain 21(5), 78-81

Thompson, John B. (2005). Books in the Digital Age: The Transformation of Academic and Higher Education Publishing in Britain and the United States. Cambridge: Polity Press.

Weller, Ann C. (2001). Editorial Peer Review: Its Strengths and Weaknesses. Medford, NJ: Information Today. 